\title{
Sovereignty and Submission
}

Luther's Political Theology and the Violence of Christian Metaphysics

Published August 2018 in: Studies in Christian Ethics, 31:435-451

Given the shifting friend-enemy constellations throughout history, theology can become a political tool of revolution as well as counter-revolution.

Carl Schmitt ${ }^{1}$

By Marius Timmann Mjaaland, University of Oslo

Professor of Philosophy of Religion, Faculty of Theology, University of Oslo, PO Box 1023 Blindern, NO0315 Oslo, Norway. Email: m.t.mjaaland@teologi.uio.no

\begin{abstract}
The classical controversy between Carl Schmitt and Eric Peterson goes directly to the heart of the matter: What is 'political theology' all about? Is it a descriptive or normative endeavour, oriented towards history or political influence on contemporary issues? This article explores these questions with reference to Protestant theology, in particular the writings of Martin Luther.

Protestant theology has often emphasised the basic difference between the spiritual and political spheres, but I question the validity of this distinction within Luther's theology. When Luther enters the political scene, an apocalyptic understanding of friend and enemy tends to dominate his thinking. Furthermore, I discuss whether this is compatible with his metaphysical understanding of the 'bidden God' in his majesty, and hence, whether this metaphysical violence is deeply embedded in Luther's theology, possibly even his understanding of 'justification by faith.' Finally, I suggest a reconsideration of Luther's political theology based on the questions raised by Schmitt and Peterson.
\end{abstract}

Keywords: metaphysics, violence, political theology, friend, enemy, apocalyptic, deus absconditus, Carl Schmitt, Martin Luther

\section{Introduction}

As is well known, Martin Luther emphasised the need for a sharp distinction between theology and politics with his doctrine of the two regiments. ${ }^{2}$ This doctrine entails a critique of the political influence of the Roman-Catholic Church on the one hand, and the revolutionary aspirations of the enthusiasts and Anabaptists on the other. At the same time, the Reformation from 1517 onwards was a highly political movement, and Luther was seen as its theological and political leader. Could

\footnotetext{
${ }^{1}$ Carl Schmitt, Political Theology II (Cambridge: Polity Press, [1970] 2008), p. 42.

2 See John R. Stephenson, 'The Two Governments and the Two Kingdoms in Luther's Thought,' Scottish Journal of Theology, Vol. 34:4 (1981), pp. 321-337.
} 
he thereby remain faithful to the basic distinction between theology and politics, or did he betray this distinction with his political activities? Are there implicit political elements of his theology that run counter to his own doctrine? Or is there, in fact, an overarching metaphysical framework that influences Luther's theology as well as his politics?

Church historians and systematic theologians who have analysed Luther have often taken the distinction between politics and theology at face value. ${ }^{3}$ Hence, political influence has been studied according to historical circumstances, whereas theological positions have been analysed in relation to either biblical texts or key notions in philosophy and theology from the $15^{\text {th }}$ and $16^{\text {th }}$ century. Marxist historians have been the most important exception to this tendency, studying Luther's theology as ideology and superstructure for class interests. ${ }^{4}$

However, the controversy between Carl Schmitt and Eric Peterson on political theology is based on a different approach. Schmitt argued that all political and juridical concepts, even modern and secular ones, are based on theological notions, whereas Peterson rejected this assertion by proclaiming the end of any political theology. ${ }^{5}$ In line with Schmitt, but based on Peterson's historical analysis of monotheism, Giorgio Agamben has more recently studied the intellectual history of the notion of God as an indication of shifting understandings of power and governance. ${ }^{6}$ Hence, with Schmitt and Agamben, the very distinction between politics and theology is undermined by historical investigations into notions of power, violence, sovereignty, and friend/enemy relations.

This makes possible a somewhat different critical approach to Luther's thinking and political praxis: an inquiry into his theological concepts as presuppositions for his political influence, both in the $16^{\text {th }}$ century and subsequent centuries. As I have argued in The Hidden God, these concepts are not merely theological, in the scriptural sense, but are also metaphysical, expressions of a particular understanding of how the world is to be organised and governed. ${ }^{7}$ They are deeply influenced by metaphysical notions among the scholastics, but also by the political circumstances in Germany in

\footnotetext{
${ }^{3}$ Cf. Thomas A. Brady, 'Luther and Society: Two Kingdoms or Three Estates? Tradition and Experience in Luther's Social Teaching,' Lutherjabrbuch 52 (1985), pp. 197-224; Gerhard Ebeling, 'The Necessity of the Theology of the Two Kingdoms' in Word and Faith, tr. J. W: Leitch (Philadelphia: Fortress, 1963), pp. 386-406; William H. Lazareth, Christians and Society: Luther, the Bible, and Social Ethics (Minneapolis: Fortress, 2001).

${ }^{4}$ Cf. Abraham Friesen, Reformation and Utopia: The Marxist Interpretation of the Reformation and Its Antecedents (Wiesbaden: Steiner, 1974).

${ }^{5}$ See Carl Schmitt, Political Theology: Four Chapters on the Concept of Sovereignty (Cambridge, Mass.: MIT Press, [11922] 1985), p. 36; Erik Peterson, 'Der Monotheismus als politisches Problem', in Ausgewählte Schriften, ed. by Barbara Nichtweiß, vol. 1 (Würzburg: Echter, 1994), pp. 23-82; here: p. 59.

${ }^{6}$ Giorgio Agamben, The Kingdom and the Glory (Stanford, Cal.: Stanford University Press, 2012).

${ }^{7}$ See Marius Timmann Mjaaland, The Hidden God: Luther, Philosophy, and Political Theology (Bloomington: Inidiana University Press, 2016).
} 
the $16^{\text {th }}$ century, and by biblical notions of sovereignty, conflict, and violence from the Old Testament, Paul, and the Apocalypse. This article thus presents and discusses some of the basic traits of Luther's political theology, with an emphasis on the implicit and explicit violence of Christian metaphysics.

In what follows, I first set out the discussion between Schmitt and Peterson on the alleged closure of any political theology. Second, I proceed to Luther's understanding of grace and sovereignty, before setting out the metaphysical foundation of this understanding. Next, I examine Luther's political interventions during the Peasants' War (1524-25). I conclude this article by broadly reconsidering Luther and the political.

\section{Luther on Sovereignty and Grace}

The classical debate between Carl Schmitt and Eric Peterson has become seminal for contemporary understanding of political theology. Carl Schmitt famously argued in Political Theology: Four Chapters on the Concept of Sovereignty (1922) that all "significant concepts of the modern theory of the state are secularized theological concepts not only because of their historical development [...] but also because of their systematic structure [...]." ${ }^{8}$ The question of sovereignty is decisive here, since Schmitt identifies the sovereign as the preeminent power, even within the fragile democracy of the Weimar Republic - due to $\int 48$ in the German Constitution, which regulates the state of exception (Ausnabmezustand). ${ }^{9}$ Schmitt would later become a supporter of Hitler and the NSDAP, and his text would be read as a political-theological argument in favour of dictatorship. Hence, the monarchic question of the sovereign was understood as directly related to monotheism and one singular power, as opposed to the separation of powers between a legislature, an executive, and a judiciary, as is the case in American and French theories of the state. ${ }^{10}$

As a subtle rejection of Schmitt, Eric Peterson in 1935 argued that Christianity introduced the closure of any political theology, specifically due to its Trinitarian understanding of the concept of God. ${ }^{11}$ For Peterson, political theology is connected either to polytheism or monotheism, the latter exemplified by Eusebius' Arian heresy and support for the Christian emperor Constantine. With Augustine's doctrine of the Trinity, Peterson argues, any such monarchic political theology is

\footnotetext{
${ }^{8}$ Carl Schmitt, Political Theology: Four Chapters on the Concept of Sovereignty, tr. George Schwab (Cambridge, Mass.: MIT Press, 1985), p. 36.

${ }^{9}$ See Schmitt, Political Theology, pp. 5-7; 14-15; cf. pp. xix-xx in the translator's Introduction.

10 "In the struggle of opposing interests and coalitions, absolute monarchy made the decision and thereby created the unity of the state." Schmitt, Political Theology, pp. 48-49.

${ }^{11}$ Cf. Peterson, 'Der Monotheismus', pp. 42-44; 57-59.
} 
rendered impossible. ${ }^{12}$ This argument became particularly popular among political philosophers and theologians after World War II, broadly as a basis for rejecting Schmitt and the authoritarian tendencies of the 1930s. However, does this historical example from the fourth century still have relevance with respect to a more modern convergence of politics and theology? And is Peterson right in claiming that the doctrine of the Trinity introduced the closure of any political theology?

These questions ought to be explored from at least three perspectives:

(i) from a descriptive and historical perspective. Does Trinitarian theology exclude the possibility of political theology?

(ii) from a normative perspective. Are political arguments based in theology legitimate, regardless of whether it is a polytheist, strictly monotheist, or Trinitarian theology?

(iii) from a political perspective. Is it acceptable to use political theology in defence of a specific regime or ideology in a particular historical situation?

The last of these is probably the real issue at stake in Peterson's argument against Schmitt. By the time Peterson wrote his critique of political theology in 1935, Schmitt had become a loyal supporter of Hitler and the NSDAP. Peterson thus viewed Schmitt's position as a natural consequence of his previous texts on dictatorship, on political theology, and on The Concept of the Political (1927). ${ }^{13}$

Martin Luther gives limited attention to the Trinity directly in his writing. Nonetheless, there is a certain consensus among scholars that his entire theology is structured as a Trinitarian theology. ${ }^{14}$ Luther is more explicitly focused on the relationship between God the Father and the Son, and this relationship is decisive for his doctrine of justification by faith alone. When human beings relate to God through Jesus Christ, Luther argues, they are judged and found guilty by the Almighty, but also forgiven, justified, and drawn into grace due to Jesus' salvific death and resurrection. This assertion follows basic theological patterns of understanding in the $16^{\text {th }}$ century. What is more controversial is Luther's sharper insistence on the unconditional character of grace, by faith alone. In particular, Luther emphasizes the paradoxical logic of the cross, e.g. in the Heidelberg Disputation, defended on $26^{\text {th }}$ April 1518. Accordingly, God is confirmed as the sovereign and the believer is

\footnotetext{
12 "Doch die Lehre von der göttlichen Monarchie mußte am trinitarischen Dogma und die Interpretation der Pax Augusta an der christlichen Eschatologie scheitern. Damit ist nicht nur theologisch der Monotheismus als politisches Problem erledigt [...], sondern auch der Bruch mit jeder 'politischen Theologie' vollzogen, die die christliche Verkündigung zur Rechtfertigung einer politischen Situation mißbraucht.” Peterson, 'Der Monotheismus', pp. 58-59. ${ }^{13}$ See Carl Schmitt, Die Diktatur, 3 ${ }^{\text {rd }}$ ed. (Berlin: Duncker \& Humblot, [11921] 1964); The Concept of the Political, trans. George Schwab (Chicago: The University of Chicago, [11927] 1996).

${ }^{14}$ See Christine Helmer, The Trinity and Martin Luther: A Study on the Relationship between Genre, Language and the Trinity in Luther's Works 1523-1546 (Mainz: von Zabern, 1999).
} 
confirmed as subjected to the power of the almighty. Still, this subjectivity is also the basis for a new dignity and freedom, coram hominibus, and for a certainty of salvation, coram Deo. ${ }^{15}$

After publishing the Heidelberg Disputation, Luther became increasingly involved in political issues from 1520 onwards. He is quite clear in his advice to the German nobility about resisting the power of the Pope, even while he tries to remain faithful to Augustine's division between the heavenly and worldly kingdom, that is, between the spiritual and political regiments. At the same time, Luther still argues for a sovereign God in the strong sense of the term. His emphasis on the sovereign God "in his majesty" results in a strong tension within his theology, and specifically in his doctrine of God. While these theological tensions have been thoroughly discussed by scholars, less attention has been given to the implications of this for his political theology, including his controversial interventions during the German Revolution in $1525 .{ }^{16}$

\section{The Hidden God}

Both the controversies surrounding Martin Luther in the $16^{\text {th }}$ century and the debate between Schmitt and Peterson in the 1920s and 1930s suggest that there is not a straightforward connection between doctrinal issues and political influence. At the same time, theological convictions are often deeply intertwined with political ideas. The analysis of how the two spheres are interrelated thus requires careful and thorough investigation. Hence, I will discuss Luther's metaphysical argument for a sovereign God, before proceeding to the relationship of this metaphysical monotheism to Luther's political-theological discussions with the Roman-Catholic Catharinus and the Radical Revolutionary Thomas Müntzer on the apocalypticism of the Book of Daniel.

The hidden God, deus absconditus, is a notion that often comes up in Luther's early texts up until 1525. The expression is taken from the Latin translation of Is. 45:15: "Vere tu es deus absconditus."17 Thus, Luther emphasizes that God in many respects remains unknown to us, in the sense of being a mystery or an inaccessible power. There are at least three different ways in which Luther uses this phrase: first, it relates to the mystical experience of God's presence, as expressed in his Lectures on the Psalms (1513/15). He there refers to Dionysius Areopagita, and his interpretation comes close

\footnotetext{
${ }^{15}$ See Martin Luther, Heidelberg Disputation, LW 31, 53; WA 1, 362. Luther's Works [LW] are quoted from the standard American edition, edited by Jaroslav Pelikan and Helmut T. Lehmann; second reference to the Weimarer Ausgabe [WA]: D. Martin Luthers Werke, Kritische Gesammtausgabe (Weimar: H. Böhlau, 1883-1929).

${ }^{16}$ See e.g. Gerhard Ebeling, 'Existenz zwischen Gott und Gott,' in Ebeling, Wort und Glaube Vol. II, (Tübingen: Mohr Siebeck, 1969), pp. 257-286; Eberhard Jüngel, 'Quae supra nos, nihil ad nos', in Jüngel, Entsprechungen: Gott - Wahrheit - Mensch (München: Kaiser, 1980), pp. 202-252.

17 "Truly, you are a hidden God." (Is 45:15)
} 
to the logic of negative theology: God is beyond reason and being, but is experienced in the passive acceptance of God's superiority, and sacrifice in Christ, which runs counter to reason. ${ }^{18}$

The second way Luther uses deus absconditus connects to his rigorous critique of scholastic theology in the Heidelberg Disputation (1518). For Luther, when we acknowledge the God who is hidden at the cross, in suffering and death, this implies a destruction of speculative theology. This destruction is important for Luther's Christological emphasis on the Word of God and sola scriptura. Where speculations on God's glory are left behind, human beings are forced to acknowledge the paradox of faith in Jesus Christ, which gives preference to the cross rather than glory, to suffering rather than strength, to the experience of evil rather than good, and finally to the transformation of life through death and resurrection, rather than a mere continuance of life that neglects the reality of death. $^{19}$

Third, Luther appeals to the deus absconditus in The Bondage of the Will (1525), when debating the problem of God's majesty with Erasmus of Rotterdam. ${ }^{20}$ Luther here insists on the absolute biddenness of God's majesty, the almighty, whose will is absolutely sovereign and free, but whose ways and reasons are unsearchable. ${ }^{21}$ While the hiddenness presented in the Heidelberg Disputation is also discussed in The Bondage of the Will, there are two distinct notions of divine hiddenness in the latter: On the one hand, God's hiddenness on the cross, which Jüngel has labelled "precise" hiddenness; on the other hand, the "absolute" hiddenness, which Jüngel insists should be "no concern of ours." 22

When Luther discusses how God is hidden "in his majesty," then, this is an example of monotheism in the metaphysical sense, rather than being a theological notion of divine government. ${ }^{23}$ Luther supports the sovereign power of the Ruler in the political regiment, whose power is derived from the absolute power of the almighty (and hidden) God. At the same time, however, God still works with two hands, one within the spiritual and the other within the worldly (political) regiment. At one level, Luther thus reformulates Augustine's theology of the two kingdoms, denying that there is any direct connection between the two regiments. Accordingly, the political role of the church is restricted to its ethical admonitions and its liturgical praxis, viz. the distribution of the

\footnotetext{
18 See Mjaaland, The Hidden God, pp. 90-91.

${ }^{19}$ Luther, Heidelberg Disputation, LW 31, 52-53; WA 1, 361-62.

${ }^{20}$ Cf. my detailed discussion of the three forms of divine hiddenness in: Mjaaland, The Hidden God, pp. 89-108.

${ }^{21}$ Cf. Luther, De servo arbitrio, LW 33, 139; WA 18, 684-685.

${ }^{22}$ Cf. Eberhard Jüngel, 'Quae supra nos, nihil ad nos'.

${ }^{23}$ Cf. the expression in Peterson, originally a quotation from Adolphe Thiers, used to describe the cosmic monarch in Aristotle's cosmology: “Le roi règne, mais il ne gouverne pas.” Peterson, 'Der Monotheismus,' p. 27.
} 
sacraments and proclamation of the gospel. ${ }^{24}$ And the nobility is made responsible for the power of the sword, acting on God's behalf with the authority and duty to use violence as and when necessary. ${ }^{25}$

Nonetheless, it is far from clear that Luther himself remained faithful to this division in his own political activities and in his role as an adviser to the German princes. ${ }^{26}$ The most prominent example of this is his activity during the Peasants' War (1524-25). To be clear, Luther viewed himself as primarily a theologian and priest, i.e. as part of the spiritual regiment. But the Reformation was never merely a spiritual and theological event - it was political from the outset. And it became increasingly political throughout the 1520s and up until the Diet of Augsburg in 1530. Moreover, theological positions were always mixed with political agendas on various sides, not only for the Emperor and the Pope, but even more significantly for the German nobility and the radical reformers. Practically speaking, it was impossible for Luther to clearly distinguish between two regiments in his own role as a Reformer. His theological positions - including the metaphysical notion of God - were thus significant for his political positions, and vice versa.

My own hypothesis is that after 1523 Luther sought to distinguish between a Christological understanding of the Church and the spiritual regiment, in particular when it comes to his emphasis on justification by faith alone, and a metaphysical representation of the sovereign God (in the scholastic and nominalist sense) within the worldly regiment. Hence, I will now examine these specific aspects of his theology in more detail. Having outlined this crucial distinction in Luther's theology, I will then return to his account of the relationship between the two regiments, as well as to questions of whether the hidden God 'in majesty' can be seen as monotheistic, and whether the hidden God 'on the cross' can be seen as Trinitarian, in the way that Peterson has drawn this distinction.

\section{Luther's Metaphysical Notion of Divine Sovereignty}

The major difference between the Heidelberg Disputation (1518) and On the Bondage of the Will (1525) is that Luther in the latter enters the metaphysical debate with full force. The question of metaphysics comes up with the problem of free will, which is the central point of contention in

\footnotetext{
${ }^{24}$ See Luther, 'Temporal Authority: To What Extent it Can Be Obeyed,' LW 45, 98.

${ }^{25}$ On Luther's doctrine of the two regiments, cf. John R. Stephenson, 'The Two Governments and the Two Kingdoms in Luther's Thought,' pp. 321-337 and W. D. J. Cargill Thompson, The Political Thought of Martin Luther (Brighton: Harvester Press, 1984), pp. 36-61.

${ }^{26}$ Cf. Hermann Kunst, Evangelischer Glaube und politische Verantwortung: Martin Luther als politischer Berater (Stuttgart: Evangelischer Verlagswerk, 1976), pp. 91-96.
} 
Luther's controversy with Erasmus. Luther discusses the notion of God in relation to causality and insists on causal necessity of all events, a form of divine voluntarism. On the other hand, he returns to the theological claim about the hiddenness of God on the cross, which is also the crux of revelation. Throughout The Bondage of the Will there is a tension between the two lines of theological inquiry, which reaches its climax with Luther's declaration of the absolute hiddenness of God "in his majesty." 27

The heart of the controversy is concerned with the nature and identity of God: Erasmus argues that if there is no freedom of will, then God must be directly responsible for evil, and for the suffering and injustice in the world. Hence, he insists that there must be some sort of liberum arbitrium (free will), even if it is a very weak and fallible will, in order to secure God's perfect goodness. ${ }^{28}$ Luther rejects the argument and the premises for it. God as revealed to us in Scripture is good and nothing but good, but the almighty is also so much more than the God we know from scripture: he is and must be beyond the distinction between good and evil. This is the hidden God, whose will is more secret than the deepest and most confusing cave. Luther adopts a radical position, given the logical and ontological premises found in medieval philosophy. He argues for a strong necessity in God's will; hence, not only is God asserted to be the first cause behind all things, he is also perceived as the effective cause in every causal relation, ordering the world according to his sovereign will:

The Sophists have labored for years over this point, but in the end they have been beaten and forced to admit that everything happens necessarily, though by the necessity of consequence (as they say) and not by the necessity of the consequent [consequentis]. They have thus eluded the violence of this question [violentiam istius quaestionis], or indeed it might rather be said that they have deluded themselves. For how meaningless this is I shall have no difficulty in showing. ${ }^{29}$

When Thomas introduced this distinction between necessitas consequentiae and necessitas consequentis, it was not only in order to distinguish between necessity and contingency, but also in order to enable a temporal qualification of existence and causation as opposed to a logical one. Hence, Thomas wanted to distinguish between the logical inference from reason to consequence (even in God's thought) and the causal relationship between cause and effect. ${ }^{30}$ This distinction is definitely useful,

\footnotetext{
${ }^{27}$ Cf. Luther, On the Bondage of the Will, LW 33, 140; WA 18, 684.

${ }^{28}$ The discussion of metaphysics in this and the following two pages summarises the analysis in Mjaaland, The Hidden God, pp. 71 and 73-75 and include passages taken directly from the original text.

29 "Sudaverunt hic sophistae iam multis annis et tandem victi, coacti sunt concedere, Omnia quidem necessario fieri, necessitate consequentiae (ut dicunt) sed non necessitate consequentis. Sic eluserunt violentiam istius quaestionis, verum et seipsos potius illuserunt. Quam sit enim hoc nihil, non gravabor ostendere." Luther, De servo arbitrio, LW 33, 39-40; WA 18, 616. Translation modified.

30 See Simo Knuuttila, Medieval Modalities (London: Routledge 1993), pp. 120-21.
} 
in philosophy as well as in theology, and can be helpful for distinguishing between ideas (metaphysics) and significant decisions (politics, ethics, etc.) in the $16^{\text {th }}$ century. However, when Luther deliberately blurs the distinction as such in favour of the necessitas consequentis, existence is emphasized over essence, causation over logic, and will over reason. Is this an attempt at weakening or delimiting the impact of metaphysical discourse? Or is it, on the contrary, an attempt to unveil the inherent violence of metaphysics?

I have come to suspect that the inherent violence of his metaphysical rationale is not exactly softened by the collapse of this distinction between two forms of necessity. If we assume that political issues are at stake in theological and metaphysical arguments, either because theology reflects politics or vice versa, then his justification of the ruler's sovereign decision throws a less flattering light on Luther's intervention against the peasants only a few months earlier. As is well known, Luther had argued that the princes ought to "stab, beat, and kill" the disobedient rioters. ${ }^{31}$ It is difficult to judge whether this (presupposed) notion of the almighty, hidden and frightening God triggers the violent political potential of the sovereign, or, conversely, whether the political violence supported by Luther some months earlier is justified by reference to an unsearchable and hidden God. In any case, the political violence corresponds to the theological-metaphysical violence, and the reference to a hidden God (beyond predication) who belongs to the sacred sphere of divinity at the very least does not prevent this violent excess during the German Revolution of 1525.

Hence, we come to the most pressing issue: The transition from metaphysics to politics, from theology to conflict and concrete forms of violence. Luther can hardly be accused of eluding the violence of the question. Rather, he goes all in. At the same time, he remains sceptical of metaphysical answers to questions of truth, in the normative sense. There is a paradoxical protest against the entire metaphysical framework which is raised from within this discourse, and this questioning of the framework is situated at the heart of the problem.

The modal logic of absolute necessity raises the question of violence (i.e. whether violence happens by necessity) inherent to any metaphysical system, from within that very system. This point of view requires a more subtle analysis of the different discourses interfering in the controversy between Erasmus and Luther. At least four such discourses converge in the question of free will, and none of these are entirely unaffected by the paradoxical structure of the problem: (i) metaphysical, (ii) (onto-) theo-logical (concerning God's essence, properties, and works), (iii) anthropological and

\footnotetext{
${ }^{31}$ See Luther, Against the Robbing and Murdering Hordes of Peasants, LW 46, 54; WA 18, 361.
} 
Christological, and (iv) political. Before turning to the political, I will briefly indicate the role of the second and third discourses.

The most crucial issue for Luther is the question of grace, namely, that humans are saved by God's grace alone. He argues that human works have no co-operative role in this revelation of grace. Rather, any pursuit of good deeds is counter-productive, an expression of human pride and selfsufficiency. For Luther, as long as humans have not understood this basic point, they are working against God.

How can human beings work "against" God if God works all in all? Indeed, it is always possible. Humans are not to be considered puppets; they are able to resist God's will in a certain sense. The surprising point in Luther is that they most often do so precisely when they imagine doing well, since the goodness of grace always runs counter to human expectations. The "free" will which insists on human freedom from God will eo ipso run counter to God's will, as a result of human hubris and pride (original sin). In this sense it is antagonistic, and causes antagonism and even bloodshed in the political sense. ${ }^{32}$ Hence, for Luther the alleged freedom of will in Erasmus' argument is an illusion, and a dangerous one at that. By contrast, real freedom requires submission to God's word and judgement.

On the other hand, when God is reconsidered according to Scripture (and not mere metaphysics), we are able to recognise that God saves human beings through law and gospel. And in order for this to occur, God must be sovereign and humans must be subjected to God's 'inner' will. This turn towards a reconciliation of God and human beings (justification) is described as a basic change of the relationship, yet at the same time a transition into a sphere of freedom. The freedom of a Christian, which is without fear and (somewhat mystically) grounded in God alone, i.e. in God's grace, is proclaimed to be the only significant freedom.

All of this indicates that there is a deep division running through Luther's notion of God, despite his insistence that he is referring to exactly the same God, perceived from two perspectives: the alien work of God (opus aliena) vs. the proper work of God (opus proprium), law and grace, condemnation and justification, etc. My concern here is not with whether this is a convincing way of understanding the Christian concept of God. Rather, my main point is simply that both law and grace require the acceptance of God's sovereignty and thus human submission. Does this emphasis on submission also extend to the sphere of politics?

\footnotetext{
${ }^{32}$ See Luther, Bondage, LW 33, 52-53; WA 18, 626.
} 


\section{Metaphysics between Theology and Politics}

When Luther begins to make interventions into politics, this seems to have largely been prompted by external events and circumstances, rather than governed by a strategy or ideology grounded in his theological writings. Hence, given his fairly conventional theology of state and church (i.e. two regiments), it becomes all the more important to look at the kind of justification he gives in controversies with his political and theological adversaries, such as Thomas Müntzer and Ambrosius Catharinus. This is the point at which metaphysical and theological arguments ought to be carefully sorted out in order to identify their political implications.

Carl Schmitt's definition of the political in The Concept of the Political is helpful for reconsidering Luther's somewhat confused, but definitely influential, approach to political conflicts: "The specifically political difference $[\ldots]$ is the difference between friend and enemy." ${ }^{33}$ Luther seemed to set out with a rather pragmatic and traditional understanding of friends and enemies prior to 1517 , but his position gradually changes when he and his followers encounter threats, resistance, and excommunication. Increasingly, he started defining friends and enemies in a more absolute sense. His definitions were still inherently theological, however: If you have the right understanding of works and grace, Word and faith, you are our friend - if not, you belong to Satan! By the time of the Peasants' War, also referred to as the German Revolution of 1524-25, this rhetoric has become even more radicalised. Historically, this is a "state of exception," the point of actual war, where chaos is threatening and regular political restrictions of violence are suspended. Luther saw this conflict as a fight over the Word of God, where bloodshed was unavoidable, and where decisive limits needed to be drawn between friends and enemies. ${ }^{34}$

Given Luther's theoretical distinction between politics and theology, the political authorities were responsible for maintaining external order - including questions of civil order, law, social issues, and wars - whereas the church was to take responsibility for the inner life, above all the administration of Word and sacraments and the salvation of the souls. The Heidelberg Theses were clearly focusing on the question of theology in terms of salvation, thus emphasising God's hiddenness under the contrary: power in weakness, lord as servant, etc. In The Bondage of the Will, this is no longer sufficient for Luther. He raises the question of metaphysics, including who and

\footnotetext{
${ }^{33}$ Carl Schmitt, Der Begriff des Politischen (Hamburg: Hanseatische Verlagsanstalt, ${ }^{31933), ~ p . ~ 7 . ~ M y ~ t r a n s l a t i o n . ~}$

${ }^{34}$ See Mjaaland, The Hidden God, pp. 164-65.
} 
what God is, his power, and his interventions in the world. Metaphysics is addressed in Aristotelian terms; whereas his political considerations now follow a more apocalyptic logic.

The problem, then, is that Luther's turn to metaphysics opens the possibility for an unrestricted exercise of power in the name of God - not only within, but also beyond the church, namely, in the sphere of politics. This is not an entirely non-theological sphere, though. Rather, it becomes a sphere of apocalyptical struggles between light and darkness, between good and evil.

This position has consequences for the connections between soteriology, metaphysics, and political theology. As we have seen, Luther's insistence on the priority of God's grace not only involves liberation, but also requires unconditional submission to God. His soteriology requires an absolute God in order to emphasise that salvation is the work of God alone, and not of human beings. Admittedly, this is a message given to humans under the contrary (sub contrario) in order to avoid ecclesial triumphalism. Luther thus points at the "destruction" of theology of glory so as to puncture the pride of the theologian. However, even the cross ultimately reflects the glory of the almighty, given to us (pro nobis) in the form of grace. ${ }^{35}$

In Luther's metaphysics, this ratio of unconditional sovereignty becomes all the more evident. Against those who think of God as weak, he underscores that the God of Christian confession is not finally powerless - since that would give us an impotent, "ridiculous" God. ${ }^{36}$ Hence, the "violence of the question" [violentiam istius questionis] concerning omnipotence is answered with reference to an omnipresent and almighty God.

To be clear, this metaphysical notion of God is not necessarily related to violence in the political sphere. But it may still justify such violence in the name of God in a less direct way. And this is exactly where we enter the sphere of the political. Although a critic of apocalypticism and the Book of Revelation in one sense, Luther still does not hesitate to apply the Book of Daniel and the apocalyptic notion of the Antichrist in his polemics, initially against Rome and then against Müntzer and the enthusiasts. His reflections on the violent conflict between different Christian factions (later also directed towards Jews and Turks, i.e. Muslims) are difficult to imagine without the metaphysical framework that I have outlined here.

\footnotetext{
${ }^{35}$ Cf. the argument presented in: Mjaaland, The Hidden God, pp. 45-48.

${ }^{36}$ Cf. the expression "Deus ridiculus": Luther, On the Bondage of the Will, LW 33, 191; WA 18, 719.
} 


\section{Politics of the Apocalypse}

As outlined above, Carl Schmitt, in his discussion of the concept of the political, identified the political difference as the difference between friend and enemy. ${ }^{37} \mathrm{He}$ sought to emphasise the basic character of this distinction, defining it as a "concrete and existential" difference, rather than as a symbolic or allegorical one. ${ }^{38}$ This existential emphasis, and related rejection of the allegorical, is in accordance with Luther's reading of the apocalyptic Book of Daniel. According to Schmitt, the difference between friend and enemy as such does not lead to war, but war remains a constant possibility. And philosophically, this possibility is defined as a presupposition for the category of the political. $^{39}$

In the theoretical elaboration of this concept, Schmitt pointed at the intensity of the relationship to either a friend or enemy as decisive for the "power" of the political. ${ }^{40}$ Although there are political relationships of various kinds and intensity, he considers the "state of exception" (Ausnabmezustand) to be the test case for the question of sovereignty, and thus also for the ultimate decision concerning friend and enemy, war and peace. ${ }^{41}$

Schmitt's discussion of how political theories relate to the dogma of sin, and in particular original sin, is relevant for this analysis. ${ }^{42}$ He follows Troeltsch's argument that any sect denying original sin will "destroy every social order." Consequently he sees a methodological relationship between theological and political premises, but argues that scholars often confuse the latter with the former due to "moral fictions" or "practical opportunism." However, Schmitt does not discuss whether this methodology runs from theology to politics or vice versa. I will thus take Luther and his enemies as a case study.

When it comes to violent conflicts, in politics as well as theology, Luther is antagonistic rather than 'agonisitic' in his thought. ${ }^{43} \mathrm{He}$ challenges his adversaries and provokes them until he is able to identify them as either enemy or friend. This is a premise for his theological thinking: The scandal (skandalon) of theological arguments ought to provoke a reaction from his opponents. Hence,

\footnotetext{
${ }^{37}$ Carl Schmitt, Der Begriff des Politischen, p. 7.

38 Ibid., p. 9.

${ }^{39}$ Ibid., p. 17.

40 Ibid., p. 21.

${ }^{41}$ Ibid., pp. $20-21$.

42 Ibid., pp. 45-46.

${ }^{43}$ For the relevance of this distinction in political philosophy, cf. Chantal Mouffe, On the Political (London: Routledge, 2005), pp. 29-30.
} 
Luther's rhetoric is intentionally scandalous, and he sees Paul as a paragon of such speech or writing. ${ }^{44}$

I have elsewhere studied some of Luther's most intensive political conflicts, and the ways in which he draws on apocalyptic patterns in order to establish this distinction between friend and enemy. ${ }^{45}$ It is Ambrosius Catharinus Politus, a theologian and law scholar in Rome, who drew the Book of Daniel into the debate (1520). At the time when Luther had been excommunicated, Catharinus identified him as one of the heretical enemies of the king, to be destroyed by the "big rock" described in Daniel 6. This rock is identified with Peter and the Vicarius Christi in Rome. Hence, the adversary of the Pope (Luther) can be identified as the enemy of Christ: the Antichrist. ${ }^{46}$

In 1521, Luther then reads exactly the same texts, but reads them otherwise. He is extremely careful in his analysis and reads the Book of Daniel according to its literal sense (in Hebrew). ${ }^{47}$ The many images of the text require close interpretation, but just like Catharinus, Luther sought to apply them directly to his contemporary theological and political situation, the papal church and its "facies" (illusions, visions, appearances). He condemned the facies as fraud, arguing that Pope Leo X's claim to represent Peter is invalid. ${ }^{48}$ When Leo claimed to be Christ's vicar on earth, this very claim revealed him as the opposite: the Antichrist. Hence, the most serious allegations against Luther are given in return. He condemned the Holy See in its late-medieval form as a fraud and a sign of the coming of Antichrist. ${ }^{49}$ Thus the story runs: Mutual allegations increase the level of intensity in the political-theological sense. There is no doubt about the distinction between friend and enemy for both sides.

A few years later, in 1524-25, Luther ends up in another controversy where the book of Daniel plays a key role. This was his big dispute with the apocalyptic and charismatic preacher Thomas Müntzer, who understood the words of freedom and justice/justification more literally than Luther, as a political message about revolution and a sign of the Last Judgement and the Kingdom of God on earth. Müntzer was early on a supporter of Luther and had visited Wittenberg in order to listen to his lectures. Captured by the radical message of the freedom of a Christian, he moved on to other towns in southern Germany and Bohemia. The Prague Manifesto was Müntzer's scandal in

\footnotetext{
${ }^{44}$ See Antónia Szabari, “The Scandal of Religion: Luther and Public Speech in the Reformation” in: Political Theologies, ed. Hent de Vries and Lawrence E. Sullivan (New York: Fordham University Press, 2006), pp. 122-36.

${ }^{45}$ See Mjaaland, The Hidden God, pp. 141-166. In the following I draw upon the extended argument, and hence there are a few passages and formulations taken from The Hidden God.

${ }^{46}$ Cf. Ambrosius Catharinus, Apologia, ed. Josef Schweizer (München: Aschendorffsche Buchhandlung, 1956), p. 224.

${ }^{47}$ Cf. Luther, Ad librum Ambrosii Catharinum responsio, WA 7, 728-29. The book is not translated into English, hence I refer to the Latin text only.

${ }^{48}$ Luther, Ad librum, WA 7, 719 and 729; cf. also the list of abuses WA 7, 762-67.

${ }^{49}$ Luther, Ad librum, WA 7, 772.
} 
Bohemia, where he became the charismatic leader of a revolutionary movement before fleeing back to Germany. He rejected Luther's loyalty to the princes and argued that upheavals were necessary in order to fulfil the political mission of the gospel, in particular the Gospel of Luke. ${ }^{50}$ Müntzer also drew upon the Book of Daniel for understanding the contemporary historical situation. $\mathrm{He}$ styled himself as a prophet with great visions, who would restore the Kingdom of God on earth. In a sermon at Allstedt, when King Fredrick was present, he claimed that God would support the poor in a final battle with the princes.

This led to a situation of doubt among the princes: What if Müntzer were right? What if God would support the peasants? Would they become the enemies of God? They thus sought clarification from Luther. Initially, Luther declared his support for the peasants and appealed to the nobility to provide better conditions. But when the peasants began plundering monasteries and organising violent protests and revolts, Luther saw society as on the verge of chaos, and called for the establishment of order. On this basis he insisted that the princes had a divine commission to use the sword, and hence he wrote:

Therefore, dear Princes, here you can liberate, here you can save, and here you can help! Have mercy with the poor people! And then—stab, beat, kill, whoever can! If you die thereby, lucky you! You could never get a more blessed death. ${ }^{51}$

As soon as Luther positioned the rioting peasants as Sons of the Devil, he declared what in modern terms would be a 'state of exception': The normal restrictions to violent action were suspended and this declaration was followed by bloody conflict between princes and peasants. Indeed, Luther justified the slaughter of up to 100000 people, who were hunted down and killed through revenge acts upon villages that had supported the peasant revolt. This state of exception (as defined by Schmitt) is thus theologically circumscribed by an apocalyptic conceptuality. And the disastrous result shows how disunited the early Reformation remains on this issue. Luther's role in the conflict is of course controversial, but he never admitted any failure, even while he made a rare effort at explaining and defending his intervention after the fact. ${ }^{52}$

\footnotetext{
${ }^{50}$ For details on Müntzer's biography, cf.: Hans-Jürgen Goertz, Thomas Müntzer: Apocalyptic Mystic and Visionary (Edinburgh: T\&T Clark, 1993).

${ }^{51}$ Luther, Against the Robbing and Murdering Hordes of Peasants, LW 46, 54; WA 18, 361. My translation.

${ }^{52}$ Cf. An Open Letter on the Harsh Book. Against the Peasants, LW 46, 63-85; WA 18, 384-401.
} 


\section{Reconsidering Luther and the Political}

Some consequences of Luther's involvement in this and other political controversies have been disastrous. Perhaps the sharpest critique directed towards the Lutheran legacy on occasion of the $500^{\text {th }}$ anniversary of the Reformation is based on this differentiation between friend and enemy. When Luther sought to enter the political sphere, his rhetoric quickly turned violent, and this violent enmity was directed with equal force against Papists and enthusiasts, Jews and Turks. They were all perceived as enemies of the truth (according to Luther), and thus as enemies of God. Indeed, within this apocalyptic framework of understanding, they are construed as at war with the good powers and the Word of God. The logic of apocalypticism allowed for demonising and totalising the enemy as universal and evil, as one who deserved to perish a violent and even eternal death. $^{53}$

This is not merely a coincidental aspect of Luther's political involvement. On the contrary, his metaphysics and theology of the hidden God, as outlined above, relates closely to his political interventions. Luther's political interventions correspond to his metaphysical notions of necessity and omnipotence, and also his theological notion of the hidden but almighty God. Is Luther then a representative of monotheism in the political sense that Peterson rejects? Or is Luther a counterexample who, like Augustine, was able to distinguish between the two regiments?

Luther's arguments in the political controversies of his time are clearly theological, following the logic of scripture. Hence, his theology of the worldly regiment is indeed a political theology, which conforms to a metaphysical monotheism. His political theology emphasizes the sovereignty of the ruler - in heaven and on earth - and the demand for submission to authorities. Given the three alternatives outlined above, Luther is neither merely descriptive nor analytical: He writes theological tracts and letters that deliberately intervene in the political course of events. They are intended as normative interpretations of scripture and have concrete political consequences, e.g. from the apocalyptic visions of Daniel. Hence, to me it seems doubtful whether Luther was capable of distinguishing clearly between the different aspects of his theology (political, soteriological, ecclesiological), and their theoretical justification. Moreover, his political theology can hardly be seen as Trinitarian. On the contrary, he suspends the question of grace and justification as irrelevant.

When Luther's most crucial discovery, the existentially shattering and liberating message of justification by faith alone, is applied in the political sphere, he apparently becomes angry and

\footnotetext{
${ }^{53}$ For further discussion, see Mjaaland, 'Apocalypse and the Spirit of Revolution,' in Political Theology 14 (2013), pp. 155-173 and ibid., 'Der apokalyptische Zwerg der Revolution,' in: Deutungsmacht, ed. Philipp Stoellger (Tübingen: Mohr Siebeck, 2014), pp. 205-224.
} 
confused. He sometimes even feels betrayed by his own followers. The radical reformers see it as a revolutionary message, whereas Luther - who was a political dissident in 1517-20 - becomes a spokesman of counterrevolution in 1524-25. Within only a few years he thus confirms Carl Schmitt's claim in the second volume of Political Theology: "Given the shifting friend-enemy constellations throughout history, theology can become a political tool of revolution as well as counter-revolution." ${ }^{54}$ In 1525 it was both, and indeed Müntzer was more inclined to apply Trinitarian perspectives (including the Son and the Spirit) in the political spheres than was Luther.

Hence, despite presupposing a Trinitarian understanding of the notion of God in his theology as a whole, Luther's notion of the political sphere appeals to a monotheistic and thus sovereign ruler. This case contradicts Peterson's claim about the "end" of any political theology, although it confirms his warnings about the potentially disastrous consequences of such monotheistic aspirations. Even more problematic is the apocalyptic narrative which dominates the understanding of history on both sides. It is by no means neutral or innocent; it seems to exacerbate the conflict towards a violent slaughter between friend and enemy, classes and confessions.

A complex question, then, is how this apocalyptic political theology relates to the Trinitarian thinking which is integral for Luther's theology of grace, as well as for his ecclesiology, his anthropology, etc. The question is of course too complex for a thorough discussion here, but it is worth noting that Luther turns to the paradox of the cross every time that it comes up. The logic of the cross subverts and destabilizes the logic of power and glory. Hence, there are some indirect, but profoundly political, consequences of this Trinitarian thinking, too, ones which run counter to his monotheistic metaphysics. Yet in the final instance, Luther obviously sees no serious conflict between his political interventions and his understanding of salvation as by grace alone. The theology of glory and cross has a reverse side: a political theology of conflictual enmity that requires bloodshed and war.

The standard theological response to Luther's problematic political interventions has often been to insist more firmly on his doctrine of the two kingdoms or 'regiments,' that is, to leave wars to political authorities and to turn towards a purely interior understanding of faith and love, salvation and eternal bliss. But this doctrine of the two regiments harbours some dangers, too. It became evident in the 1930s in Germany, when this doctrine was commonly used as an argument against political protest. The Protestants who were loyal to Hitler, the so-called Deutsche Christen, argued with Paul's admonitions in Romans 13, where he urged Christians to remain faithful to the

\footnotetext{
${ }^{54}$ Carl Schmitt, Political Theology II, p. 42.
} 
authorities, since the rulers are appointed by God (Rom 13:1-5). Hitler on this basis tried to make the Protestant churches an instrument of his regime. And today, in 2018, it is simply astonishing to observe how the same passage from Paul's Letter to the Romans has been used by the US attorney general in order to defend a strict immigration policy on the Mexican border. ${ }^{55}$

On the other hand, it is often argued that the Confessing Church, under the leadership of Karl Barth, Martin Niemöller, and Dietrich Bonhoeffer, was significant precisely because it rejected a sharp division between state and church, and pursued a different approach: Theology ought to disclose the true nature of a regime and, when necessary, mobilise for political and spiritual opposition. The political controversies of the 1930s thus also caused theological conflicts over political issues, and given the extreme situation it was seen as an eschatological struggle between light and darkness, the kingdom of God and the Third Reich. This was later perceived as the 'good' political theology, as opposed to Schmitt's four chapters on sovereignty, but it was basically an argumentation based on the 'monarchic' sovereignty of the Almighty - in Barth's case explicitly so.

For a contemporary reconsideration of Luther's political theology, such observations are of course important. The relationship between politics and religion is complex, and law scholar Paul W. Kahn argues that even modern secular states can create their own sacred space and sacred history, based on a glorious past and an apocalyptic or eschatological expectation of the future. In doing so, they are in some respects the heirs of pre-modern political theologies. The relationship between politics and religion is as profound as ever, yet more complex and difficult to identify:

Political theology does not just challenge a particular configuration of legal institutions, as if the question were one of scaling down the separation between church and state. It challenges the basic assumptions of our understanding of modernity, the nature of individual identity, and the character of the relationship of the individual to the state. ${ }^{56}$

In order to better understand the structures of modern states it is therefore necessary not only to study the discontinuity but also the continuity between premodern, modern, and late modern political theologies. The point of such analyses would not be to reinforce a political theology of monotheism or Trinitarian Christianity. On the contrary, the analysis will first of all be descriptive, and yet identify the conceptual and normative interdependence of politics, metaphysics, and theology.

\footnotetext{
55 https://www.independent.co.uk/voices/jeff-sessions-immigration-children-parents-separated-bible-romans-13a8405856.html [22/06/2018]

${ }^{56}$ Paul W. Kahn, Political Theology: Four New Chapters on the Question of Sovereignty (New York: Columbia University Press, 2011)
} 
The political theology of Luther can be understood on the basis of the conflicts provoked by the Reformation. As a historical event, the Reformation was significant because of the deep political conflicts that emerged and played out through in an antagonistic logic of friends and enemies. The prophetic and apocalyptic framework in the Book of Daniel was instrumental for expressing these conflicts, that is, as narratives of universal war between good and evil, between the followers of Christ and Antichrist. In Luther's theology, there were no metaphysical limitations on such enmity. He rejected scholastic definitions which he found superfluous, but by doing so, he provided a basis for a more absolute kind of metaphysical and political violence: the almighty God was perceived as a sovereign ruler, beyond reason. In later years, a similar pattern of friends and enemies was easily extended to the Muslims (Turks) and the Jews.

The study of political theology can be applied as model for modern dictatorship, as Schmitt was accused of doing. But it can also have the opposite effect, as a warning against such plots which more or less produce the enemy according to a particular narratival logic (such as apocalypticism) and which enhance the dynamics of war. The second half of the $20^{\text {th }}$ century was dominated by such historical and political metanarratives of the West against the rest, in particular against the enemies behind the iron curtain. In the $21^{\text {st }}$ century the narratives are shifting, and so too is the perception of enemies. However, whether the enemy is called Al-Qaida or ISIS, Iran, Russia, or North Korea, there is a continuous need to create narratives that justify threats and violence, according to a dramatic, even apocalyptic historical logic.

To be clear, the social and political mechanisms of the $16^{\text {th }}$ century are rather different from our own post-modern and global world. Nonetheless, studying the narratives of power and sovereignty and the construction of enemies in the $16^{\text {th }}$ century remains helpful for identifying similar structures today, in a more complex world - also in order to avoid that theology and philosophy too easily become the tool of shifting ideological constellations, revolutions as well as counter-revolutions. These are exactly the kind of questions Carl Schmitt pressed in the second volume of Political Theology from 1970, which again has become a highly topical issue of political philosophy and theology today. 